\title{
Ethnomedicinal survey of some plants used for the treatment of diabetes in Ibadan, Nigeria
}

\author{
Ofuegbe S.O. and Adedapo A.A \\ Department of Veterinary Physiology, Biochemistry and Pharmacology, University of Ibadan, Nigeria
}

Objectives: A comprehensive survey with the aim of documenting traditional medicinal practices was carried out in targeted areas of Ibadan, Nigeria in order to inventory plants used by traditional healers in the area for the management of diabetes. Materials and Methods: Open-ended informal interviews were administered during series of repeated visits to the respondents consisting majorly the traditional medical practitioners (TMPs) and herb sellers. Some traditional healers who know and use medicinal plants for treating diabetes mellitus were interviewed. The inventory contains scientific, vernacular, common names of the plants used and methods of preparation. Results: Twenty seven plants commonly used by traditional healers in the region were identified. These plants were found to be very important and useful in the treatment of diabetes based on their frequency of occurrence in the recipes obtained. Herbal remedies were either prepared from dried or freshly collected plants while traditional solvent of choice included water, lime, local gin and aqueous extract from fermented maize. Decoction and pulverization were the main methods of preparation while mode of administration varies within 1 to 3 times daily. Survey revealed that leaves form the major part of plants for herbal preparations. Residents in the study area find traditional medicine cheaper as compared to orthodox medicine. Conclusion: This review focuses on the various plants that have been reported to be effective in the treatment of diabetes. The survey shows that plants from the Rubiaceae, Labiataceae, Meliaceae, Hypoxidaceae and Cucurbitaceae families are commonly used by traditional healers in Ibadan for the treatment of diabetes mellitus.
Access this article online

Website:

http://nepjol.info/index.php/AJMS

DOI: 10.3126/ajms.v6i5.10480

Key words: Ethnomedicine, Diabetes, Survey, Medicinal Plants

\section{INTRODUCTION}

In diabetes mellitus a chronic endocrine disorder, abnormally high blood glucose is the major feature. It is characterized by altered metabolism of carbohydrates, lipids, and proteins coupled with an increased risk of vascular and renal diseases. ${ }^{1-3}$ Though despite harmful side effects, insulin and synthetic oral hypoglycaemic agents are widely used in management of diabetes. ${ }^{4}$ It is as a result of these harmful side effects that, herbal remedies are also preferred because they are safe for long-term use, easily accessible, and cost effective hence many rural dwellers could easily afford these. It is also in recognition of this that the ethnomedicine is of great interest in the scientific world in the past decades or so.
Ethnomedicine is concerned with the study of medical systems from the native's point of view. In ethnomedicine, native categories and explanatory models of illness including aetiologies, symptoms, courses of sickness and treatment are investigated., ${ }^{5,6}$ The ethnomedical approach is very useful in the study of indigenous therapeutic agents because it allows the researcher to understand the treatment patterns according to native explanatory models. Furthermore, in order to preserve traditional medicinal knowledge, it is necessary that inventories of plants with therapeutic value are carried out and the knowledge related to their use documented in systematic studies. Ethnomedicinal surveys provide the rationale for selection and scientific investigation of medicinal plants since some of these indigenous remedies have been successfully used by significant numbers of people over extended periods 
of time. ${ }^{7}$ According to the World Health Organization, at least $80 \%$ of people in developing countries depend largely on indigenous practices for the control and treatment of various diseases affecting both human beings and their animals. ${ }^{8}$ The surveys also help the conservation of traditional knowledge through the identification of medicinal plants with market potential that can generate incomes for local communities [Figure 1].

Diabetes mellitus is a metabolic disease characterized by high blood glucose level resulting from defects in insulin secretion, insulin action or both. ${ }^{9}$ It is a chronic disorder that affects the metabolism of carbohydrates, fats, proteins and electrolytes in the body, leading to severe complications which are classified into acute, sub-acute and chronic. Acute complications include hypoglycaemia, diabetic ketoacidosis, hyperosmolar and hyperglycaemic non-ketotic syndrome, ${ }^{10}$ while sub acute complications include thirst, polyuria, lack of energy, visual blurriness and weight loss, ${ }^{9}$ chronic hyperglycaemia causes glycation of body proteins which in turn leads to complications that may affect the eyes, kidneys, nerves and arteries. ${ }^{11}$ It is a major health problem with its frequency increasing every day in most countries. ${ }^{12}$ The prevalence of diabetes mellitus is on the increase worldwide and it is still expected to increase by $5.4 \%$ in $2025 . .^{13}$

Herbal medicine is known to play an important role in diabetic therapy, particularly in the developing countries where most people have limited resources and do not have access to modern treatment. ${ }^{14}$ In the last few years there has been an exponential growth in the field of herbal medicine and these medicinal plants are gaining popularity both in developing and developed countries because of their natural origin and less side effects. ${ }^{15}$ Based on the historical success of natural products as antidiabetic agents,

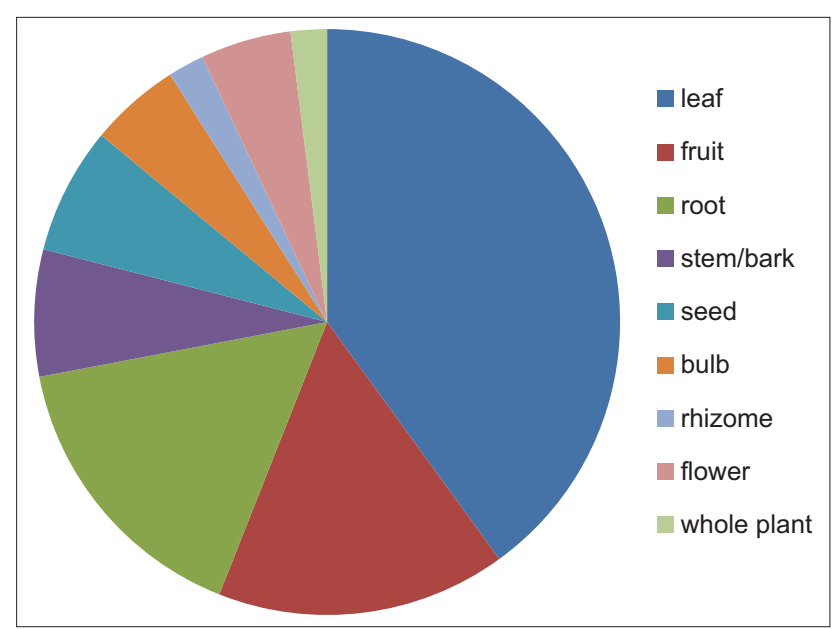

Figure 1: Percentage occurrence of plant parts used for diabetes treatment the side effects associated with the use of orthodox drugs such as insulin and oral hypoglycaemic agents and the ever increasing need for new antidiabetics, there is an increase in demand for the use of plant based medicines to treat diabetes. ${ }^{16}$ Another important factor that strengthens the use of plant materials as anti diabetics could be attributed to the belief that medicinal plants do provide some benefits over allopathic medicine and allow the users to feel that they have some control in their choice of medication. ${ }^{17}$

The aim of this survey was to compile the different indigenous plants in Ibadan used for the management of diabetes.

\section{MATERIALS AND METHODS}

\section{Study area}

Ibadan is the capital city of Oyo state and the third largest metropolitan area by population in Nigeria with the total estimated population of 1,338,659 according to 2006 census, The land area is 3,080 square kilometer. ${ }^{18}$ Ibadan came into existence in 1829; it is located in the south eastern part of Oyo state and south western part of Nigeria, $128 \mathrm{~km}$ inland northeast of Lagos and $530 \mathrm{~km}$ southwest of Abuja. Ibadan is classified as a derived savannah, it has a tropical wet and dry climate with a lengthy wet season and relatively constant temperatures throughout the course of the year. The city is naturally drained by four rivers with many tributaries including Ona river, Ogbere river, Ogunpa river and Kudeti river. The people are mainly Yoruba people; the main indigenous occupation of the people is farming.

\section{Ethnomedicinal survey}

The main data sources consisted of a series of informal interviews and general conversation administered on the local herb sellers and other groups of people rich in traditional medicine knowledge. The interviews were done in their native language (Yoruba language), while the information gathered was sorted, the data collected included the local names of plants and parts of the plants used. The plants were identified by their vernacular names and later validated at the Department of Botany, University of Ibadan.

Descriptive statistics such as pie chart and percentages were used in the analysis of the data.

\section{RESULTS}

\section{Respondents' identity}

All the respondents were females with $65 \%$ within the age range of $41-50$ years, $25 \%$ within the age range of 51-60years, while about 10\% were above 60years. All of 
them were married; $90 \%$ of the respondents were herb sellers and 10\% were traditional medical practitioners. Majority of the respondents were either primary school leavers or secondary school leavers and most of them claimed that they inherited their vocation and ethnomedicinal knowledge from their parents. All the respondents were Yoruba speaking people.

\section{Ethnomedicinal survey}

A total of 27 plants were described as being used for the treatment of diabetes, plant forms include the climbers, herbs, shrubs and trees. The plant parts used mostly

\begin{tabular}{llc}
$\begin{array}{l}\text { Table 1: Demographic characteristics of the } \\
\text { respondents on the knowledge of plants used in } \\
\text { the treatment of diabetes }\end{array}$ \\
\hline Variables & Specification & $\begin{array}{c}\% \text { age of } \\
\text { respondents (\%) }\end{array}$ \\
\hline Age & $41-50$ & 65 \\
& $51-60$ & 25 \\
Marital status & $>60$ & 10 \\
\multirow{2}{*}{ Practice } & Married & 100 \\
& Single & 0 \\
Sex & Traditional practitioners & 10 \\
& Herb sellers & 90 \\
Educational status & Male & 0 \\
& Female & 100 \\
& Sectiary institution & 0 \\
& Primary school & 25 \\
\end{tabular}

from the identified plants include the leaves, fruits and roots [Table 1]. Prominent among the plant species mentioned for the treatment of diabetes mellitus are Vernonia amygdalina and Ocimum gratissimum. It was observed that recipes were made from combination of different parts from more than one plant species including fruits and leaves mostly, while some were made from single plant part. The preferred solvents in most preparation were water, soft drink, local gin and liquid from fermented maize (Table 2).

Oral administration was the only mode of administration of the herbal treatment for diabetes in the study areas in Ibadan, similarly, the method of preparation mostly preferred were by decoction, squeezing, boiling (in water), soaking, grinding/pounding, drying and pulverization into powder (Table 3).

\section{DISCUSSION}

Diabetes mellitus is a heterogeneous group of disorders characterized by abnormalities in carbohydrate, protein, and lipid metabolism. The effects of uncontrolled diabetes include inability to see clearly, recurrent boils on the skin, leg ulcers that fail to heal, frequent urination, weight loss, inordinate appetite, mental depression, progressive weakness, thirst and dry tongue. ${ }^{19}$ In Nigeria, most diabetic patients consult traditional medical practitioners (TMPs) to manage their health condition. ${ }^{20}$ As a result of this, the

\begin{tabular}{|c|c|c|c|c|c|c|c|}
\hline S/N & Plant name & Family & Local name (Yoruba) & Common name & C/W & Parts used & Habit \\
\hline 1 & Aframomum melegueta & Zingiberaceae & Atare & Alligator pepper & W & Fruit & Herb \\
\hline 2 & Ageratum conyzoides & Asteraceae & Imi-esu & Goat weed & W & Leaf, flower & Herb \\
\hline 3 & Allium ascalonicum & Liliaceae & Alubosa elewe & Shallot, leafed onion & $\mathrm{C}$ & Leaf, bulb & Herb \\
\hline 4 & Allium sativum & Liliaceae & Alubosa aayu & Garlic & $\mathrm{C}$ & Bulb, leaf, rhizome & Herb \\
\hline 5 & Ananas comosus & Bromeliaceae & Ope oyinbo & Pineapple & $\mathrm{C}$ & Fruit & Herb \\
\hline 6 & Azadirachta indica & Meliaceae & Dongoyaro & Neem tree & W & Leaf, bark, seed oil & Tree \\
\hline 7 & Brassica oleracea & Brassicaceae & Efo nyenbo & Cabbage & W/C & Leaf & Herb \\
\hline 8 & Carica papaya & Cariacaceae & lbepe & Pawpaw & $\mathrm{C}$ & Leaf, root, fruit & Tree \\
\hline 9 & Citrullus lanatus & Cucurbitaceae & Bara & Water melon & C & Fruit & Creeper \\
\hline 10 & Citrus aurantifolia & Rutaceae & Orombo & Lime & $\mathrm{C}$ & Fruit & Shrub \\
\hline 11 & Cocos nucifera & Arecaceae & Agbon & Coconut & C & Coconut water & Tree \\
\hline 12 & Curculigo pilosa & Hypoxidaceae & Epa ikun & African crocus & W & Root & Herb \\
\hline 13 & Gladiolus psittacinus & Iridaceae & Baaka & Sword lilly & W & Bulb & Herb \\
\hline 14 & Khaya senegalensis & Meliaceae & Epo oganho & African mahogany & W & Bark & Tree \\
\hline 15 & Mitracarpus scaber & Rubiaceae & Ewe idasa & Button grass & W & Leaf & Herb \\
\hline 16 & Morinda lucida & Rubiaceae & Oruwo & Brimstone tree & W & Leaf, root & Shrub \\
\hline 17 & Moringa oleifera & Moringaceae & Ewe-igbale & Horse radish tree & $\mathrm{C}$ & Leaf, seed,flower, root & Tree \\
\hline 18 & Momordica charantia & Cucurbitaceae & Ejinrin wewe & African cucumber & W & Leaf & Climber \\
\hline 19 & Musa paradisiaca & Musaceae & Ogede agbagba & Plantain & $\mathrm{C}$ & Leaf, fruit & Herb \\
\hline 20 & Ocimum gratissimum & Labiatae & Efinrin & Sweet basil & C & Leaf, root & Herb \\
\hline 21 & Perquetina nigrescens & Asclepiadaceae & Ogbo & Africa perquetina & W & Leaf, root & Climber \\
\hline 22 & Picralima nitida & Apocynaceae & Abere & Picralima & W & Seed, root,leaf, bark & Tree \\
\hline 23 & Senna alata & Caesalpiniaceae & Asunwon oyinbo & Candle bush & $\mathrm{C}$ & Leaf & Shrub \\
\hline 24 & Senna podocarpa & Caesalpiniaceae & Asunwon ibile & Candle bush & $\mathrm{C}$ & Leaf & Shrub \\
\hline 25 & Vernonia amygdalina & Asteraceae & Ewuro & Bitter leaf & $\mathrm{C}$ & Leaf & Shrub \\
\hline 26 & Viscum album & Santalaceae & Afomo & mistletoe & W & Whole plant & Shrub \\
\hline 27 & Xylopia aethiopica & Annonaceae & Eeru & Ethiopian pepper & W & Fruit & Tree \\
\hline
\end{tabular}




\begin{tabular}{|c|c|c|c|}
\hline Recipes & $\begin{array}{l}\text { Solvent of } \\
\text { choice }\end{array}$ & $\begin{array}{l}\text { Method of } \\
\text { preparation }\end{array}$ & Mode of Administration \\
\hline Picralima nitida (Seeds), cubes of sugar & $\begin{array}{l}\text { Soft drink/cocos } \\
\text { nucifera water }\end{array}$ & $\begin{array}{l}\text { Pulverization } \\
\text { after sun drying }\end{array}$ & Four tablespoonful three times daily \\
\hline $\begin{array}{l}\text { Carica papaya (Leaves), Xylopia aethiopica (Fruits), } 1 \\
\text { tablespoonful of salt }\end{array}$ & $\begin{array}{l}\text { Fermented Zea } \\
\text { mays liquor }\end{array}$ & Decoction & Half a glass cup every morning \\
\hline $\begin{array}{l}\text { Morinda lucida (Leaves), Momordica charantia (Leaves), } \\
\text { Vernonia amygdalina (Leaves), Musa sapientum (Fruits) }\end{array}$ & $\begin{array}{l}\text { Fermented Zea } \\
\text { mays liquor }\end{array}$ & Decoction & Two tablespoon three times daily \\
\hline Ocimum gratissimum (Leaf), Mitracarpus scaber (Leaf) & Salt solution & Squeezing & Three tablespoon three times daily \\
\hline $\begin{array}{l}\text { Allium sativum (Bulb), Vernonia amygdalina (Leaves), } \\
\text { Ocimum gratissimum (Leaves), Vernonia amygdalina (Leaves) }\end{array}$ & Lime & Decoction & One glass cup every morning \\
\hline Morinda lucida (roots) & Water & Boiling & A glass cup once daily \\
\hline Vernonia amygdalina (Leaves) & Water & Boiling & A glass cup once daily \\
\hline Senna alata (Leaves), sugar cubes & Lime & $\begin{array}{l}\text { Pulverization } \\
\text { after sun-drying }\end{array}$ & $\begin{array}{l}\text { Small quantity of the material is taken } \\
\text { with hot pap once in the morning }\end{array}$ \\
\hline $\begin{array}{l}\text { Carica papaya (male) (Roots), Senna podocarpa (Roots), } \\
\text { Senna alata (Roots), Citrus aurantifolia (Fruit juice) }\end{array}$ & Lime & Decoction & $\begin{array}{l}\text { One tablespoon in the morning and } \\
\text { evening }\end{array}$ \\
\hline Perquetina nigrescens (Roots), Citrus aurantifolia (Fruit juice) & Lime & Decoction & Half glass cup in the morning and evening \\
\hline $\begin{array}{l}\text { Ocimum gratissimum (Leaf), Vernonia amygdalina (Leaf) } \\
\text { Azadirachta indica (Leaf), Picralima nitida (seeds), Allium } \\
\text { Sativum ( rhizomes), Allium ascalonicum (bulbs), little potash }\end{array}$ & Water & $\begin{array}{l}\text { Squeezing and } \\
\text { blending }\end{array}$ & Three tablespoons, three times daily \\
\hline Brassica oleracea (leaves) & Water & Squeezing & A glass cup once daily \\
\hline Ageratum conyzoides (Leaves) & Water & Maceration & A glass cup once daily \\
\hline Ocimum gratissimum (leaves), Viscum album (Whole plant) & Water & Squeezing & A glass cup of the mixture three times daily \\
\hline $\begin{array}{l}\text { Citrullus lanatus (fruit), Picralima nitida (seeds), } \\
\text { Aframomum melegueta (Fruit) }\end{array}$ & Local gin & Decoction & Two tablespoons daily before breakfast \\
\hline Moringa oleifera (leaves) & Boiled water & Soaking & A glass cup regularly for some weeks \\
\hline $\begin{array}{l}\text { Curculigo pilosa (Root), Gladiolus psittacinus (Bulb), } \\
\text { Khaya senegalensis (Bark) }\end{array}$ & Water & Cooking & A glass cup once daily \\
\hline
\end{tabular}

documentation of medicinal plants used to treat diabetes mellitus is important.

From the study, It was observed that leaves formed the most frequently used part for diabetes $(40 \%)$, followed by fruits $(16 \%)$, root $(16 \%)$, seeds $(7 \%)$, stem/bark $(7 \%)$, bulb $(5 \%)$, flower $(5 \%)$, rhizome $(2 \%)$ and whole plant $(2 \%)$. The plant leaves are important ingredient in traditional treatment of various diseases as it occurred as a component in many herbal preparations. ${ }^{21}$

Majority of the herbal recipes were observed to be polyherbal (i.e. in combination), while some were prepared from single plant source. Polyherbal therapy is said to be a current pharmacological principle having the advantage of producing maximum therapeutic efficacy with minimum side effects. ${ }^{22}$ Polyherbal therapies have the synergistic, potentiative, agonistic/antagonistic pharmacological agents within themselves that work together in a dynamic way to produce therapeutic efficacy with minimum side effects. $^{23}$

\section{CONCLUSION}

The practice of traditional medicine has been from time immemorial and the rural population depends mostly on it. ${ }^{24}$ In addition to the documentation of traditional medicinal practices used for the treatment of diabetes in the study area, this study have provided the ethnomedicinal foundation for the pharmacological properties of notable medicinal plants and their therapeutic effects on diabetes. This study further strengthened the relationship between indigenous knowledge, ethnomedicinal practices, drug discovery and pharmacology. Considering the rich cultural traditions of plant use and the high prevalence of diabetes, more in vivo investigations should be encouraged in order to validate the antidiabetic activity of the identified plants as claimed by the traditional healers.

\section{REFERENCES}

1. Brunton LL, Lazo JS, Parker K. In: Goodman and Gilman's The Pharmacological basis of therapeutics.11th ed. New York City, U.S: McGraw-Hill Medical Publishing Division; 2006. pp. 1613-44.

2. Harvey RA, Champse PC. Edited Lippincott's illustrated Reviews: Pharmacology. 4th ed. Netherlands: Wolter Kluwer Publishers; 2009. pp. 287-96.

3. Kumavat UC, Shimpi SN and Jagdale SP. Hypoglycemic activity of Cassia javanica Linn in normal and streptozotocin-induced diabetic rats. J Adv Pharm Technol Res 2012; 3(1): 47-51.

4. Sammaiah G and Shrivastava RS. Hypoglycemic activity of Polygala erioptera (Whole plant) in normal and alloxan induced diabetic rats. Asian J Chemistry 2008; 2:107-112.

5. Kleinman A. Concepts and a model for the comparison of medical systems as cultural systems. Social Science and Medicine 1987; 12(2B): 85-93.

6. Kleinman A. Patients and healers in the context of culture. University of California Press, Berkeley 1980. 
7. Geerlings EC. Background information on research subjects, sheep husbandry and ethnoveterinary knowledge of Raika Sheep pastoralist in Rajasthan, India (MSc thesis) 2001.

8. Shen S, Qian J and Ren J. Ethnoveterinary plant remedies used by Nu people in NW Yunnan of China. Journal of Ethnobiology and Ethnomedicine 2010; 6:24

9. Sharma AK, Galadari EO, Behara I, Manchandra M, Adbulrazzaq SK and Mehra MK. Diabetes mellitus and its complications: An Update, in Macmillan. New Delhi 1993.

10. Knentz AJ, Nattras M, Pickup JC and Williams G. Diabetic ketoacidosis, non-ketotic hyperosmolar coma and lactic acidosis, in Handbook of diabetes. (2nd edition). Blackwell Science 1991; pp. 479-494.

11. Ahmed KA, Muniandy $S$ and Ismail IS. $\mathrm{N}_{-}$-(Carboxymethyl)lysine and coronary atherosclerosis-associated low density lipoprotein abnormalities in Type 2 diabetes: current status. J Clin Biochem Nutr 2009; 44:14-27.

12. Zimmet P, Dowse G, Finch $C$, Serjeantson $S$ and King $H$. The epidemiology and natural history of NIDDM-Lessons from the South Pacific. Diabetes Metabolism Review 1990; 6:91-124.

13. Moller DE and Flier JS. Insulin resistancemechanism, syndromes and implications. N Engl J Med 1991; 325: 938-948.

14. Ajaiyeoba EO, Ogbole $\mathrm{OO}$ and Ogundipe OO. Ethnobotanical survey of plants used in the traditional management of viral infections in Ogun State of Nigeria. European J Sci Res 2006; 13(1): 64-73.

15. Modak M, Dixit P, Londhe J, Ghaskadbi S and Devasagayam TPA. Indian herbs and herbal drugs used for the treatment of Diabetes. J Clin Biochem 2007; 40: 163-173.
16. Marles R, Farnsworth NR, Wanger $\mathrm{H}$ and Farnsworth NR. Plants as Sources of antidiabetic agents in: Economic and Medicinal Plant Research. Academic press limited UK 1994; 6: 149-187.

17. Johshi BS and Kaul PN. Alternative medicine: Herbal drugs and their critical appraisal- part 1. Progress in Drug Research 2001; 56: 1-76.

18. Areola $\mathrm{O}$. The spatial growth of Ibadan city and its impact on rural hinterland. Rex Charles publication, Ibadan; 1994

19. Bella AF. What a layman should know about Diabetes. Published by Pen Services, Ibadan; 1997.

20. Jegede A, Oladosu P, Ameh S, Kolo I, Izebe K and Builders P. Status of management of diabetes mellitus by traditional medicine practitioners in Nigeria. Journal of Medicinal Plants Research 2011; 5(27):6309-6315.

21. Adekunle MF. Indigenous Uses of Plant Leaves to Treat Malaria Fever at Omo Forest Reserve (OFR), Ogun state, Nigeria. Ethiopian Journal of Environmental Studies and Management 2008; 1(1): 31-35.

22. Ebong PE, Atangwho IJ, Eyong EU and Egbung GE. The Antidiabetic Efficacy of Combined Extracts from Two Continental Plants: Azadirachta indica (A. Juss) (Neem) and Vernonia amygdalina (Del.) (African Bitter Leaf). American Journal of Biochemistry and Biotechnology 2008; 4(3):239-244.

23. Tiwari AK and Rao JM. Diabetes mellitus and multiple therapeutic approaches of phytochemicals: Present status and future prospects. Current Science 2002; 83(1):30-37.

24. Adedapo ADA, Adeagbo AS and Adedapo AA. Use of botanical therapies among patients in secondary health facilities in Southwest Nigeria: implications for medical education. Recent Progress in Medicinal Plants 2013; 35 (14): 209-310. 